\title{
LIFE OF A CHINESE COURTESAN: MA SHOUZHEN (1548-1604) ${ }^{1}$
}

"I passed my childhood at the river banks, not knowing any sorrows But now the storms and rains have brought the autumn chill to Ch'in-huai. I dare not turn my head again to roads of old along the dykes. The trees are thin, the sun is low, and I am in a public house." 2

In China during the late Ming period the southern capital Nanjing, also called Jinling, experienced a period of new growing urbanity. This included the flowering of trade with southern regions, a general increasing of wealth and commerce of luxury items, the development of printing and the spreading of books which generally helped to enhance the literacy of people including women. Moreover, Nanjing was the place of the most famous pleasure quarters of the period, which were placed along the river Qinhuai in the heart of the city. There in a lively atmosphere prostitutes, courtesans, singing girls and boys were performing to entertain men of any social level. Elite courtesans, which were the highest class of sexual workers, were women well educated in order to be intellectually and artistically engaging for officials and literati. This was mainly due to the fact that during the Ming time the imperial examination took place in the Tribute Hall of Nanjing every three years and thereby the connection between courtesans and literati was particularly strong. However, this relation goes back to the Tang period $(618-907),{ }^{3}$ when courtesanship began to flourish in the ancient capital of Chang'an (today Xi'an). ${ }^{4}$

Ma Shouzhen (1548-1604) was a charming courtesan living in the entertainment quarters of Nanjing. At the age of fifteen, she was officially introduced to the Nanjing courtesan scene by the well known poet and calligrapher Peng Nian (1505-1566). ${ }^{5}$ Also known as Ma Xianglan (Ma Orchid of the Xiang River), she was trained in dancing and singing in order to become a high range professional entertainer or singing girl (geji).

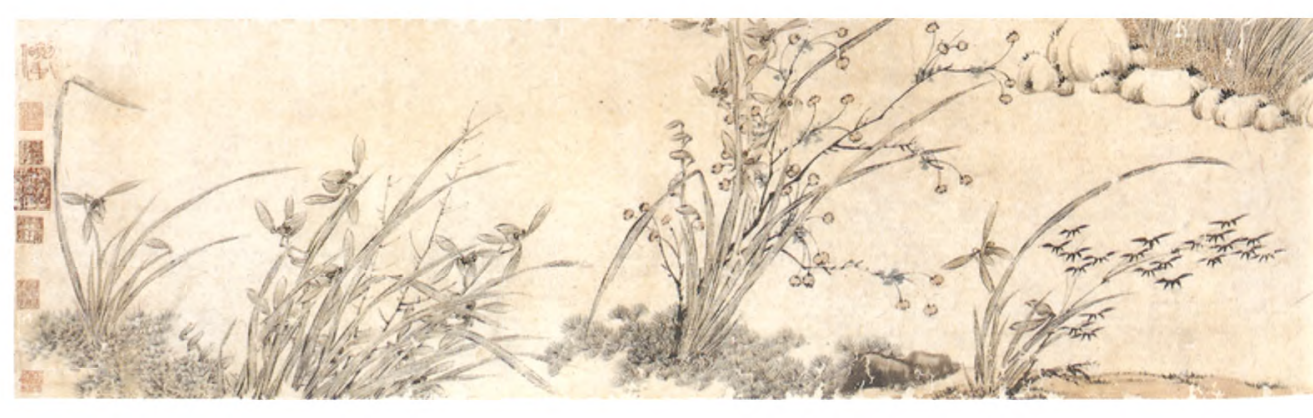




\section{Figure 2}

Ma Shouzhen, Orchid and Bamboo, ink on paper, hanging scroll (121.8 × $31.8 \mathrm{~cm}$ ), Rijksmuseum Amsterdam, E 24-025.

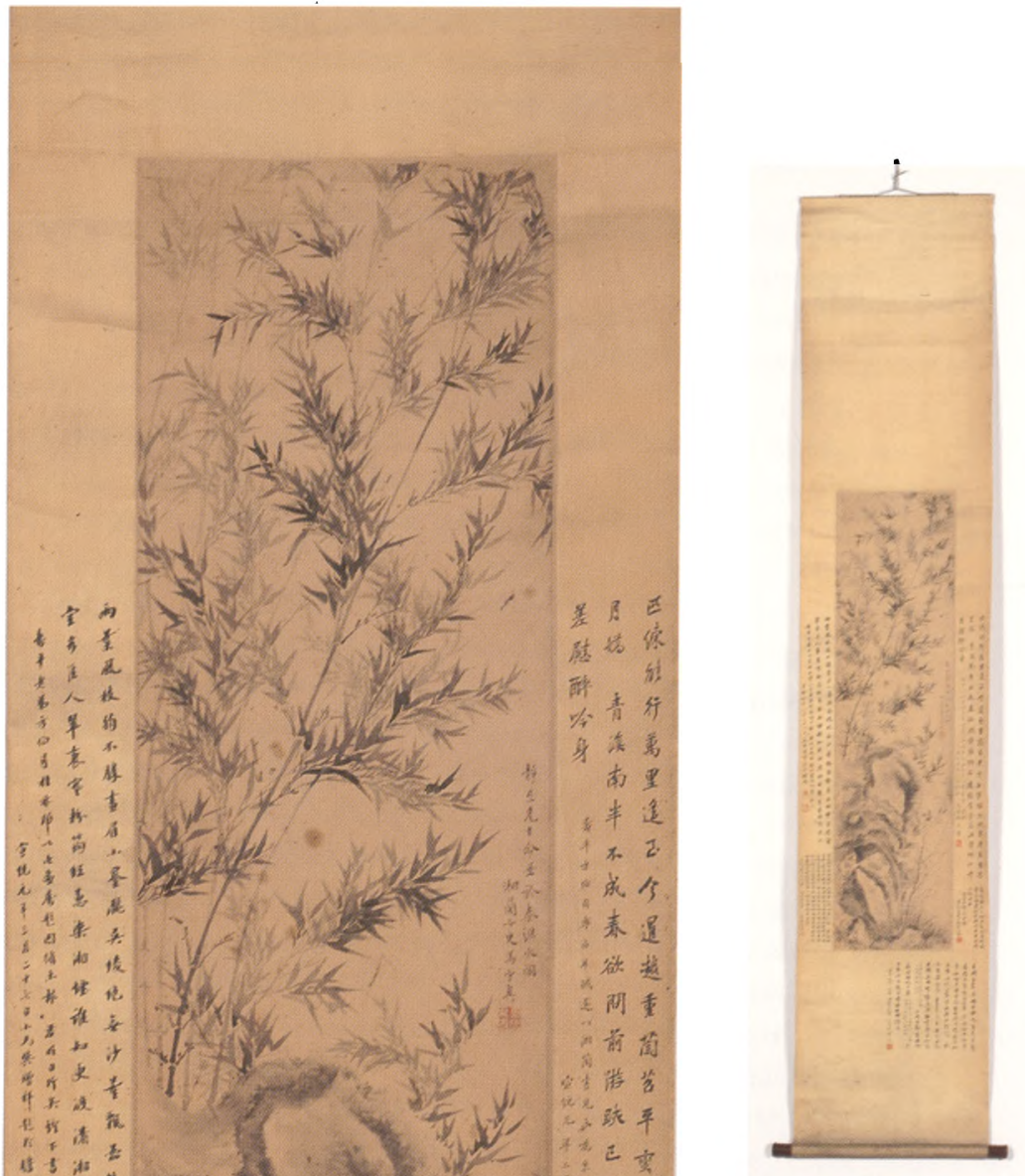

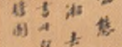

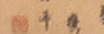

v. 14

is

1) $\frac{1}{5}$

is

$\therefore$ 아

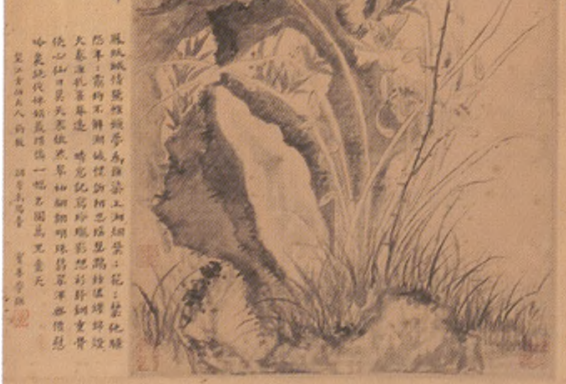

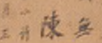

a格花本

这有证

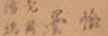

t 淂始

4 基去

国要清

你名

小者

辛的

$=$ ti

iste

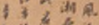

a

$4 \hat{4}$ in

is it 4 

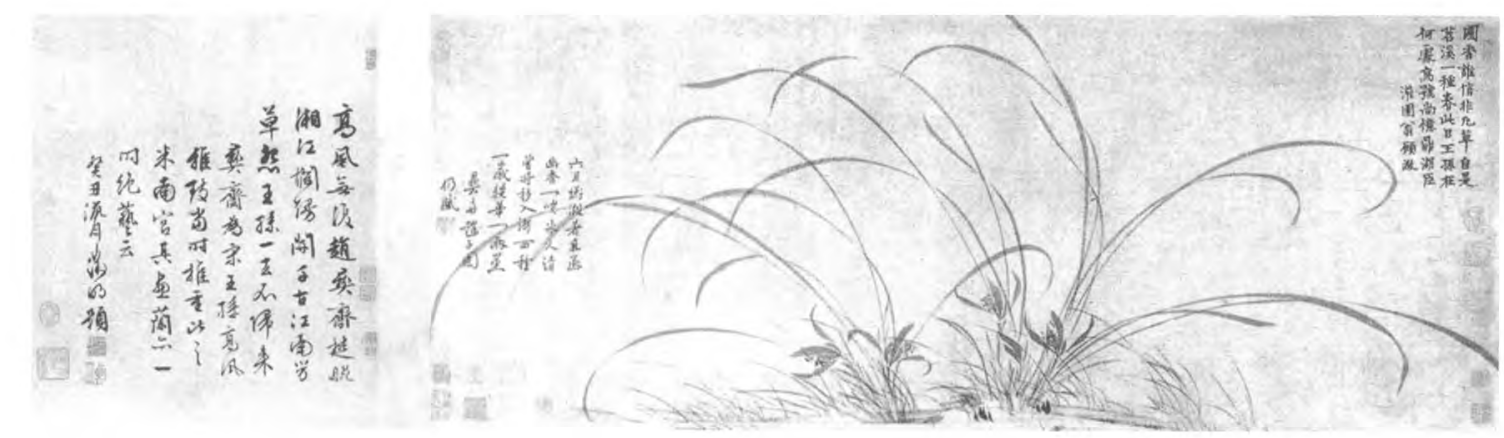

Figure 3

Zhao Mengjian, Orchids, Detail of a hand-scroll (34 ×91 cm), in: Zhongguo gudai shuhua tumu, vol. 19, 1-401.

paintings as a means for establishing social ties that could possibly enhance her position, sheds a new light on Ma's work that could not be grasped in any other way. Moreover it tightly links her biography to artistic choices building a bridge between the two main sides of this woman's existence: the artistic and the courtesan one. Ma was strongly connected to important men - such as officials and literati artists - to whom she often dedicated her paintings. The practice of giving paintings as gifts was encompassed in the exchange system of goods and services which involved different strata of Ming society, for instance courtesans and literati or officials. Ma dedicated paintings to high ranking people who could reciprocate the gift in different ways. For example, if they were poets and calligraphers they could write inscriptions on her paintings thereby enhancing her prestige as artist and courtesan. One of the most recurrent recipients of Ma's paintings was Wang Zhideng (15351612): an eminent poet and calligrapher. Not only by her paintings, but also reading her poems and letters, Wang Zhideng appears to be a constant presence in Ma's life as patron and lover. ${ }^{13}$ At the same time, Ma was acquainted with other famous courtesans working in Nanjing and the surrounding area. She collaborated with them in the production of paintings as epitomized by the hand scroll depicting flowers and plants made during a night party together with Lin Xue, Wang Dingrui and Wu Juanjuan.

Looking at Ma Shouzhen's extant art works - scrolls, fans and album leaves, half of which are today in Chinese collections, only a few in private collections, while the others are in American, European and Japanese museums - she did paint mainly orchids, bamboo and rocks. ${ }^{14}$ In Late Imperial China, orchids were visual topoi in paintings by women; ${ }^{15}$ they symbolize the literati's exclusiveness and seclusion as well as purity, ${ }^{16}$ not necessarily a woman's purity, but as Clunas suggests "also of sexually available lushness". ${ }^{17}$ Bamboo is an important subject matter in Chinese painting since the $10^{\text {th }}$ century, as it represents the intellectual qualities of the literati. On the other hand, the rock represents stability and strength and it could be interpreted as a counter balance to the fragility of the orchid flower. It is also possible to give a gender interpretation to these subjects: orchid epitomizes femininity, while the rock represents the male physical strength, and the bamboo intellectual quality. 


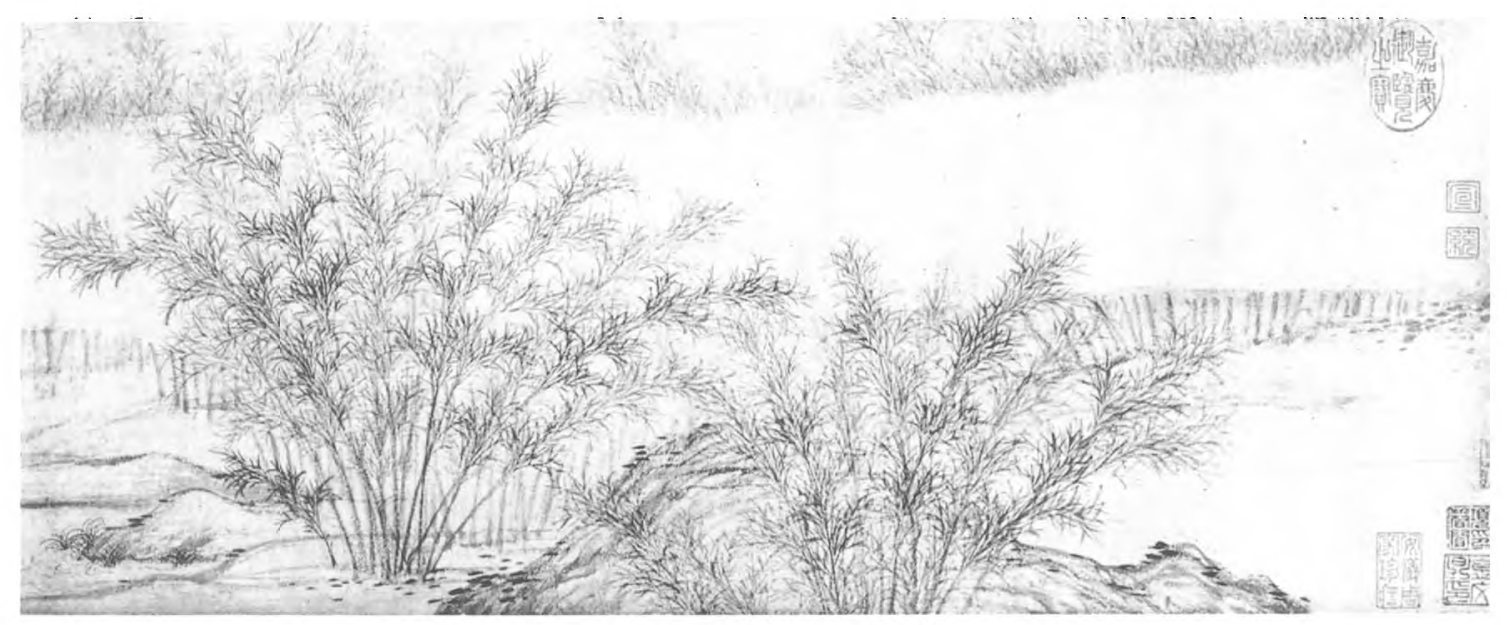

Figure 4

Guan Daosheng, Bamboo Groves in Mist and Rain, 1308, in: Weidner, Views from Jade Terrace, 1988.
Ma Shouzhen was also a respected poet and her works were included in many poetry collections compiled both during the Ming and the Qing (16441911) dynasties in which anthologies of women's poetry were very common. ${ }^{18}$ This was mainly due to the increasing female literacy rates and also to the growing commercialization of books. ${ }^{19}$ In this atmosphere of female intellectualism, in 1591 Ma Shouzhen published her own collection of poems titled Collection of the Master Orchid of the Xiang River (Xianglan Zi $J i),{ }^{20}$ to which Wang Zhideng, previously mentioned, wrote an introduction celebrating her charm. ${ }^{21} \mathrm{Ma}$ was considered to be one of the "Four Talented Courtesans of Qinhuai" (Qinhuai siji shi), as recorded in the homonymous collection of poems edited by Mao Yuchang of the Qing dynasty. ${ }^{22}$ As a poet, she belonged to the genre defined "boudoir poetry", not necessarily to indicate that the poems were written by courtesans or women in general, but to underline the feelings of grief or grievance as the major theme. ${ }^{23}$ Female poetry during the Ming and the Qing periods is characterized by a strong sense of conventionality as they expressed their feelings mainly through poetic topoi representing natural elements, such as the moon or animals, which were typically metaphors of their lives. ${ }^{24}$ In spite of this, Ma is considered to be one of the few Ming women poets to explicitly express her feelings as in this poem titled Since you went away. The last couplets clearly convey the message of her sadness: ${ }^{25}$

"Since you went away,

I am afraid to hear the maid's song.

When the song enters the abandoned one's ears,

The green robe is spattered with teardrops.

Since you went away,

No more lifting of jade cups together.

Wine is a grief-dispelling thing,

But how much can it dispel?" 26 
Ma Shouzhen spent her whole life as a courtesan although one of the main aspirations for a prostitute was to get married, become the concubine of a well-off man and settle in a family, rather than working in the pleasure quarters. ${ }^{27}$ Nonetheless, her biography records she proposed Wang Zhideng to marry her, after he saved her "from a disaster", but he refused. ${ }^{28}$ After she went to Suzhou in 1604 to arrange the celebration for his seventieth birthday, which went on for months, she died in Nanjing praying, as a devout Buddhist. ${ }^{29}$ In occasion of her death, Wang composed twelve eulogies. ${ }^{30}$

Ma Shouzhen was a famous courtesan who throughout her life enjoyed great fame as painter and poet. As an elite courtesan she refused "unworthy candidates" and accepted in her company only educated men, such as very well-known artists and poets. ${ }^{31}$ Accordingly, she was connected to important men of her period, some of which were friends, and some others probably patrons or sponsors. Thus, it is undisputed she was strongly related to the literati world through a net of acquaintances and especially through Wang Zhideng. ${ }^{32} \mathrm{Ma}$ created a network of social relationships principally in order to enhance her position as courtesan and artist. Nevertheless, many aspects of her life are still obscure and need to be further researched also in order to reach a deeper comprehension of courtesanship in the Late Ming.

\section{Noten}

1. A special thanks to Menno Fitski.

2. O. Siren, A History of Later Chinese Painting. Vol.2, New York, 1978, p. 52.

3. $P$. Yao,'The Status of Pleasure: Courtesan and Literati Connections in T'ang China (618-907)', Journal of Women's History , Vol. 14, n. 2, 2002, pp. 26-53.

4. V. Xiong, 'Ji- Entertainers in Tang Chang'an', in: Presence and Presentation. Women in the Chinese Literati Tradition, 1999, pp. 149-169.

5. Y. Tseng, 'Women Painters of the Ming Dynasty', Artibus Asiae, Vol. 53. no. 1/2, 1993, p. 252.

6. I.Y. Lo, 'Daughters of the Muses of China', in: M. Weidner (ed.), Views from Jade Terrace: Chinese Women Artists, 1300-1912, Indianapolis, 1988, p. 41.

7. Weidner, Op.cit., p. 73.

8. Weidner, Op. cit., p. 72.

9. Weidner, Op.cit., p. 73.

10. S. Li,.'Tan Mingdai nühuajia Ma Shouzhen hua lan (Discussing the orchid paintings of the Ming woman artist Ma Shouzhen)', Wenwu, no. 7, 1991, pp. 81-82.

11. L.Y.L. Chang, P. Miller, Four Thousand Years of Chinese Calligraphy, Chicago, 1990, pp. 7-8.

12. J. Yu, ed., Zhongguo Meishu Jiaren Ming Cidian (Dictionary of Chinese Artists),

Shanghai, 1981, p.1249.

13. Harvard-Yenching Library, 'Ma Shouzhen', in: The Ming-Qing Women's Writings, 2005. http://digital.library.mcgill.ca/mingqing/search/details-poet.php?poetID=2966\& showbio $=\&$ showanth $=\&$ showshihuaon=\&language $=e n g$. Accessed on 5 June, 2007.

14. I have traced around 40 of Ma's paintings.

15. E.J. Laing, 'Women painters in Traditional China', in: M. Weidner, Flowering in the Shadows: Women in the History of Chinese and Japanese Painting, Honolulu, 1990, p. 91.

16. C. Clunas, Pictures and Visuality in Early Modern China, London, 1997, p. 159.

17. Laing, Op.cit., p. 37.

18. Harvard-Yenching Library, Op.cit.

19. Chang, Op.cit., p. 147. 
20. Z. Yuan, G. Yang (eds.), Zhongguo Funü Mingren Cidian (Dictionary of Famous Chinese Women), Changchun, 1989, p. 16.

21. Tseng, Op.cit., p. 252.

22. K.I.S. Chang, H. Saussy (eds.), Women Writers of Traditional China. An Anthology of Poetry and Criticism. Stanford, 1999, pp. 230-231.

23. Lo, Op.cit., p. 45-46.

24. Chang, Op.cit., p. 6.

25. Lo 1988, Op.cit., pp. 45-46.

26. Chang, Op.cit., p. 230.

27. For marriage of courtesans see S. Mann, Precious Records. Women in China's Long Eighteenth Century, Stanford, 1997, p. 128.

28. Idema, Wilt and Beata Grant, The Red Brush:Writing Women of Imperial China,

Cambridge, 2004, p. 366; Yuan, Op.cit., p. 16.

29. Idema, Op.cit., pp. 366-367.

30. Tseng, Op. cit., pp. 252-253.

31. D. Ko, 'The Written World and the Bound Foot: A History of a Courtesan's Aura' 32. Weidner, Op. cit., p. 72. 